\title{
Alzheimer hastalı̆̆ ve beslenme ile ilişkisi
}

Meltem Pınar YILDIRIMa, Burcu ATEŞ ÖZCAN ${ }^{\mathrm{b}}$

\section{ÖZET}

Merkezi sinir sisteminin hasar görmesi sonucu meydana gelen demansın \%70'ini oluşturan Alzhiemer hastalığı, genetik ve çevresel faktörlerin bir araya gelmesiyle oluşan bir hastalıktır. Alzheimer hastalığının patogenezinde amiloid beta birikimi, Tau proteinleri, nörofibriler yumaklar yer almaktadır. İnflasmasyon, oksidatif hasar, insülin direnci, kolesterol, eser elementler, metal maruziyeti, Apolipoprotein E4 (ApoE) genini taşımak risk faktörlerindendir. Tek başına yaşlanma ile Alzheimer hastalığının ortaya çıkmadığı, çevresel faktörlere ihtiyaç olduğu bilinmektedir. Alzheimer hastalığı için kesin bir beslenme tedavisi olmamasına rağmen Akdeniz diyetinin Alzheimer hastalığına karşı koruyucu ve risk faktörlerini önleyici olduğu bilinmektedir. Meyve ve sebzelerden zengin, beyaz et tüketiminin orta seviyede olduğu, doymuş yağ asitlerinden kisitlı ve doymamış yağ asitlerinden zengin olması yönüyle dikkat çeken Akdeniz diyeti günümüzde hala popülerliğini korumaktadır. Gut mikrobiyotadaki birtakım değişiklikler Alzheimer hastalığı üzerinde etkili olabilmektedir. İnflamasyonu azaltıcı, serbest radikallerden koruyucu ve beslenme kaynaklı amiloid beta birikimini artıran faktörleri ortadan kaldıran bir beslenme programının takip edilmesi koruyucu olabilir. Bu beslenme programına ilave olarak vitamin ve mineral takviyesi ile probiyotik desteği de Alzheimer hastalığını önleyici olarak önerilmektedir.

Anahtar Kelimeler: Alzheimer hastalığı, beslenme tedavisi, nörodejeneratif hastalıklar

\section{Alzheimer's disease and its relationship with nutrition}

\begin{abstract}
Alzhiemer disease, which accounts for $70 \%$ of dementia caused by damage to the central nervous system, is a disease formed by combining genetic and environmental factors. In the pathogenesis of Alzheimer's disease, amyloid beta accumulation, Tau proteins, neurofibrillary tangles are involved. Inflammation, oxidative damage, insulin resistance, cholesterol, trace elements, metal exposure, carrying the Apolipoprotein E4 (ApoE) gene are risk factors. It is known that Alzheimer's disease does not occur with aging alone, environmental factors are needed. Although there is no definitive nutritional treatment for Alzheimer's disease, the Mediterranean diet is known to be protective and preventive against risk factors of Alzheimer's disease. The Mediterranean diet, which attracts attention with its rich consumption of fruits and vegetables, moderate consumption of white meat, limited in saturated fatty acids and rich in unsaturated fatty acids, is still popular today. Some changes in gout microbiota can affect Alzheimer's disease. Following a nutritional program that reduces inflammation, protects from free radicals and eliminates factors that increase nutritional amyloid beta accumulation can be protective. In addition to this nutrition program, vitamin and mineral supplements and probiotic supplements are recommended as a preventive for Alzheimer's.
\end{abstract}

Keywords: Alzhemier disease, nutrition treatment, neurodegenerative diseases

\footnotetext{
Geliş Tarihi:07.03.2020 Kabul Tarihi: 06.11.2020

a'stanbul Okan Üniversitesi, Sağllk Bililmleri Enstitüsü, Beslenme ve Diyetetik Bölümü, İstanbul, Türkiye, e-posta: dyt.mpinaryildirim@gmail.com ORCID: 0000-0001-9999-4786

bìstanbul Okan Üniversitesi, Sağllk Bililmleri Fakültesi, Beslenme ve Diyetetik Bölümü, İstanbul, Türkiye, e-posta: burcuates474@ @otmail.com ORCID: 0000-0003-2627-0167

Sorumlu Yazar/Correspondence: Burcu Ateş Özcan e-posta: burcuates474@ @hotmail.com
}

Atıf: Yıldırım MP, Ateş Özcan B. Alzheimer hastalığı ve beslenme ile ilişkisi. Sağlık ve Yașam Bilimleri Dergisi 2020;2(2):66-73.

Citation: Yıldırım MP, Ates Ozcan B. Alzheimer's disease and its relationship with nutrition. Journal of Health and Life Science 2020;2(2):66-73. 


\section{GíRiș}

Merkezi sinir sisteminin hasar görmesi sonucu meydana gelen biliş işlevlerinde bozulma şeklinde tanımlanan demans, işlev bozukluklarının sayısı, nasıl başladığı, süresi, şiddeti ve ne şekilde ilerlediğine bağlı olarak diğer hastalıklardan ayırt edilmektedir. Demans, primer ve sekonder şeklinde kendini göstermektedir ve Alzheimer hastalığı primer demansın en sık nedenidir. ${ }^{1}$

Alzheimer hastalığı (AH) ilk olarak Alman psikiyatrist, nöropatolojist Alois Alzheimer tarafindan bulunmuştur. Hastalığı bulduğu vakanın otopsisinde, beyninde amiloid plaklar ve nörofibriler birikimler gözlenmiştir. ${ }^{2,3}$

$\mathrm{AH}$, beyin hücrelerinin kısmi ölümüyle karakterize ve nedeni belli olmayan genetik yatkınlıktan etkilenen nörödejeneratif, kronik, günlük yaşamı ve sosyal hayatı etkileyen, geri dönüşü olmayan bir hastalıktır. Nöropsikolojik bulgular ve davranış değiş̧iklikleri diğer bulgulara eşlik etmektedir. ${ }^{4,5}$ AH'de meydana gelen patolojik değişiklikler hafiza kaybına, düşüncelerde dengesizliğe ve beyin işlevinde disfonksiyona neden olur. Hastalık yavaş ilerler ve hücre ölümü ile beyinde hasara neden olur. ${ }^{6,7}$

Ulusal Nörolojik, İletişim Bozuklukları ve İnme Enstitüsü ve Alzheimer Hastalığ 1 ve İlişkili Bozukluklar Derneği (NINCDS-ADRDA) AH'yi tanımlayan bazı kriterler oluşturmuştur. Hafiza, dil becerisi, uzamsal algı, dikkat, yürütücü işlevler, adapte olabilme, problem çözebilme ve işlevsellik kriterlerinden en az ikisinde bozulma var ise 'Muhtemel Alzheimer' tanısı alınmaktadır. ${ }^{8}$ Dünya Sağlık Örgütü (DSÖ) dünya çapında demans hastalarının yaşadığı sorunlara, demansa gösterilen anlayışa ve demans hakkındaki farkındalık eksikliğinin arttığına dikkat çekmektedir. ${ }^{9}$

AH uzun süre bakım gerektirdiğinden kaynak tüketimi fazladır. AH'nin teşhis edilmesi, tedavisi ve tedavinin devamının planlanması göz önünde bulundurulduğunda AH'nin maliyet yükü sağlık sistemi üzerinde çok fazladır. ${ }^{10}$ İki bin on yılından sonra Dünya Alzheimer Raporuna göre $\mathrm{AH}$ maliyeti 604 milyar dolar olarak tahmin edilmiştir. İlerleyen yıllarda ise daha da artış göstereceği düşünülmektedir. ${ }^{11}$

\section{Alzheimer Hastalığının İnsidansı, Prevelansı ve Etiyolojisi}

AH prevalansını ve insidansını etkileyen en önemli faktör yaştır. ${ }^{12,13}$ Türkiye İstatistik Kurumu (TÜİK) 2017 verilerine göre, ölüm nedeni istatistiklerine bakıldığında AH'den vefat eden yaşlıların sayısı ise 6 bin 155'ten 11 bin 997'ye yükselerek AH'den ölen yaşlıların sayısı 2 kat artış göstermiştir (TÜİK, 2017).
AH insidansı 65 ve 69 yaş aralı̆̆ında \%0,4 iken, 90 yaşında \%10'lara ulaşmakta; prevalansı 65 ve 69 yaş

aralığında $\% 2$ iken, 90 yaşında \%25'lere ulaşmaktadır. ${ }^{14-16}$ Altmış beş yaş üstü için prevelans beş yılda iki katına çıkmaktadır. İstanbul'un Kadıköy bölgesinde yapılan bir araştırmaya göre 70 yaşın üstündeki bireylerde $\mathrm{AH}$ prevalansı \%11 olarak bulunmuştur. ${ }^{17}$

Erken başlangıçlı Alzheimer (EOAD, presenilin) 65 yaş öncesi için kullanılan adlandırmayken, 65 yaş sonrasında geç başlangıçlı Alzheimer (LOAD, senilin) olarak adlandırılır. ${ }^{19,20}$ EOAD vakaları genelde tek gene bağlı otomozal dominant kalıtım şeklindedir. LOAD vakaları ise tek bir gen yerine birden fazla genin katkıları ile çevresel faktörlerin birleşiminden ortaya çıkar. ${ }^{2,12,18}$

\section{Alzheimer Hastalığının Patogenezi}

Alzheimer Hastalığının etiyopatogenezinde genetik faktörler, amiloid $\beta$ birikimi, endojen toksinler, glutamat birikimi, eser elementler ve serbest radikallerin nörotoksisitesi neden olarak görülmüştür. ${ }^{19}$ Bunlardan en çok anormal protein modifikasyonları ve oksidaif stres özellikle son y1llarda karşılaşılmaktadır. ${ }^{19,20}$

Zaman geçtikçe Alzheimer'ın tanımlanması, hastalığın tedavisi üzerine yapılan çalışmaların sayısını artırmıştır. AH patogenezi hakkında araștırmalar ve çalışmalar sürekli yenilenmektedir. AH için 3 adet patolojik bulgu çok önemli sayılmaktadır. Bunlar Amiloid beta $(A \beta)$, nörofibriler yumaklar (NFY), hiperfosforile Tau proteinidir. $\mathrm{Bu}$ sürecin ilerlemesinde inflamasyon, oksidatif hasar, glutamat eksitotoksisitesi, insülin direnci, kolinerjik kayıp, sinaps- nöron kaybı da etkili olabilir denmektedir. ${ }^{21}$ NFY'nin içinde hiperfosforile Tau proteinleri, senil plakların içinde $A \beta$ peptid olmak üzere beyinde bölgesel olarak birikmeler mevcuttur. Karakteristik anormal protein birikimi ve ilerleyen bir beyin atrofisi de görünür. AH için tek bir faktör yoktur. İnflamasyona bağlı gelişen tümör nekroz faktör alfa (TNF- $\alpha$ ), IL-1 (özellikle IL-1 $\beta$ ) ve IL-6'nın beyin omurilik sıvısında artış gösterdiği görülmüştür. Artmış TNF- $\alpha$ 'nın endotelyal ve mikrovasküler bozukluklarda yer aldığ ve bunun da amiloid plak oluşumunu artırdığını araştırmacılar düşünmektedir. ${ }^{22}$

Erken evre AH'nin kognitif bozulma ve insülin direnci arasındaki ilişkisi amiloid alfa artışına bağlıdır. İnsülinin birçok metabolik olayda yer aldığ 1 ve beyin metabolizması ve bilişssel fonksiyonlar üzerinde de etkili olduğu bilinmektedir. ${ }^{23}$ 


\section{Alzheimer Hastalığı ve Genetik}

AH'nin genetiğinde yer aldığı varsayılan bazı kromozomlar vardır. 21. Kromozomda amiloid prekürsör protein, 14. kromozomda presenilin1, 1. kromozomda presenilin2 EOAD ile ilişkilendirilmişken, 19. kromozomda yer alan APOE, LOAD'den sorumludur. ${ }^{2}$

Amiloid prekürsor proteininin tam fonksiyonu bilinmemesine rağmen sinaptik formasyon ve nöronal göçte etkili olduğu söylenmektedir. Amiloid prekürsor proteininin nin $\beta$ ve $\gamma$ sekretaz ile proteolitik yıkımı sonucunda meydana gelen $\beta$ amiloid $(\mathrm{A} \beta)$ AH'nin patogenezinde çok önemlidir. ${ }^{12}$ Presenilin1, amiloid prekürsor proteini ve presenilin2'ye göre hastalığın ortaya çıkmasına daha çok sebep olmaktadır. EOAD'ye neden olan presenilin1 mutasyonları tek başına hastalıkta yeterli değildir. Başlangıç yaşı, hastalığın seyrini değiştirmektedir. ${ }^{24}$ Presenilin2 mutasyonuna sahip ailelerde hastalığın başlama yaşı 45-88 gibi geniş bir yelpazededir ve Presenilin1 mutasyonu taşıyanlara göre hastalığın başlama yaşı yüksektir. AH'li vakaların beyinlerinde presenilin2 aracığı ile amiloid beta oluşumunda artış olduğu gözlenmiştir. Yapılan farklı çalışmalarda LOAD'de risk faktörü gen APOE'dir. APOE, lipoprotein kompleksinde kilit roldedir. Lipoliz ve lipid transferi ile bağlı proteinler APOE aracılığı ile taşınırlar ve APOE lipid metabolizmasında düzenleyicidir. ${ }^{2}$

\section{Alzheimer Hastalığının Risk Faktörleri}

AH gelişmesinde yaş önemli bir risk faktörü olarak bilinse de diğer risk faktörleri ile birlikte AH oluşumu meydana gelir. Apolipoprotein E4 alelleri (APOE4) taşımak, ailede $\mathrm{AH}$ olup olmaması, kafa travması öyküsü ve kardiyovasküler hastalık riskleri $\mathrm{AH}$ için sayılan diğer risk faktörleridir. ${ }^{25}$ Çevresel faktörler de $\mathrm{AH}$ için bir risk faktörüdür. Metaller, pestisitler, endüstriyel kimyasallar, hava kirliliği bu faktörlerden sayılmaktadır. Nöroinflamasyon, nöropati ve $\mathrm{AH}$ bu maddeler ile ortaya çıkabilmektedir. ${ }^{26}$

Diyabetin AH için risk faktörü olabilmektedir. Özellikle ileri yaşlanma ve dolayısı ile demans insidansı artan gelişmiş ülkelerde, diyabetin de yaş ile artış gösterdiği göz önünde bulundurulduğunda, diyabetli hastalarda biliş kaybı görülme sıklığının artacağ bildirilmektedir. $^{27-29}$

AH risk faktörlerinden biri de kolesteroldür. Diyetle alınan kolesterolün ratlar üzerindeki etkisinin incelendiği 5 aylık bir çalışmada diyette kolesterolün artırılması ile amiloid beta birikiminin ve Tau proteininlerinin yükseldiği görülmüştür. LDL ve HDL ile $\mathrm{AH}$ ilişki incelendiğinde yüksek LDL ve düşük HDL'nin $\mathrm{AH}$ riskini artırdığı gözlenmiştir. ${ }^{30} \mathrm{AH}$ ilerledikçe yağ profilinde bozulmalar başlamaktadır. Yapılan bir çalışmada AH'ye sahip olan bireylerde,
AH olmayanlara göre kan lipid düzeyleri daha düşük bulunmuştur. İleri seviye AH'nin, orta seviye AH'ye göre kan kolesterol ve LDL düzeyleri düşük bulunmuştur. ${ }^{31}$

\section{Hastalığın Bulguları ve Komplikasyonları}

Hastalığın ilk evrelerinde en çok gözlenen bulgu son yaşanan olayları anımsamada zorluk çekmektir. İlk evrede en büyük sorun bellek kaybıdır. Orta evrede kognitif defisitler artış göstermektedir ve kişi sosyal hayatına devam edememekte, ev içindeki işlerini yapamamaya başlamaktadır. İlerlemesiyle beraber duygu durum değişiklikleri, motive olamama, konuşma gibi işlevlerde kayıplar, kendi öz bakımını yapamama ve davranışların kontrolünün sağlanamaması gibi durumlar mevcuttur. İleri evrede bireylerde tam bağımlılık süreci başlamaktadır. İlerleme arttıkça bedensel işlevlerde bozulmalar artar ve ölümle sonuçlanır. Genelde tanı alındıktan 3 ila 9 yıl arasında ölüm beklenir. ${ }^{32,33} \mathrm{AH}$ başlangıcı ilk başta yaşlılık ve stres ile ayrıştırılamamaktadır. Dil, yönetici işlevler, algılama ve hareket etmede yaşanan zorluklar, hafiza sorunlarından daha bellidir. ${ }^{34}$

\section{Alzheimer Hastalığında Beslenme Tedavisi}

Bireysel ihtiyaçlara göre günlük gereksinimlerin karşılandığı ve bireyin kan değerlerinin takip edildiği diyet modellerinde Alzheimer hastalığı ve birçok hastalığın bireysel ihtiyaçlar göz önünde bulundurulmayan diyet modellerine göre daha az görüldüğü çalışmalarca gösterilmiştir. Günlük alınması gereken besinler, yeterli ve dengeli olacak şekilde, besin ögelerini içermelidir. Kişiye özgü diyet uygulaması da sağlıklı yaşam için bir zorunluluktur. ${ }^{35}$

\section{Akdeniz Diyetinin Alzheimer Hastalığı ile İlişkisi}

Farklı besinler ve diyet tarzlarının, besin ögeleri içeriklerinden dolayı bilişsel fonksiyonlar, demans ve AH üzerinde bazı etkileri vardır. AH için özellikle bir diyet belirtilmemesine rağmen $\mathrm{AH}$ patogenezinde yer alan hastalıklar için iyileştirici ve önleyici özellikleri olan Akdeniz diyeti AH'de önerilmektedir. ${ }^{36,37}$ Akdeniz diyeti (AD), ağırlıklı olarak sebze ve meyve tüketimini içerir. Tam tahıllı ürünler, kurubaklagiller, kompleks karbonhidratlar yer almaktadır. Beyaz et tüketimi orta seviyede, süt tüketimi orta seviyede; yumurta, kırmızı et, işlenmiş et tüketimi sınırlıdır. ${ }^{38,39}$ Yağ kaynağı temelde zeytinyağıdır ve doymuş yağ tüketimi olabildiğince düşüktür. ${ }^{40,41}$ Oksidatif stres Alzheimer hastalığının önemli nedenlerindendir ve akdeniz diyetinin antioksidan içeriği oksidatif stresi azaltmaktadır. ${ }^{42}$ AD'de yer alan sebze ve meyveler içeriğindeki $\mathrm{E}$ vitamini, $\mathrm{C}$ vitamini, karetonidler, flavonoidler ile; zeytinyağı içeriğindeki fenolik bileşikler ile balık içeriğindeki omega-3 ile; şarap içeriğindeki resveratrol gibi fenolik bileşikler ile oksidatif strese karşı koruyucudur. Dolayısı ile bu 
beslenme şekli ile Alzheimer hastalığının patofizyolojisinde yer alan oksidatif stres faktörü azalmaktadir. ${ }^{43-45}$

\section{Alzheimer Hastalığının Vitamin ve Mineraller ile İlişkisi}

Yapılan bir araştırma koruyucu özelliğe sahip bileşiklerin, antioksidan özelliklere sahip maddeler ve vitaminler içeren sebze ve meyvelerin diyette sıklıkla yer almasının yaşlanma sürecini geciktirdiği, beslenmeye bağlı hastalıkları, kalp ve damar, kanser gibi hastalıkları, akciğer hastalıklarını, bazı göz hastalıklarını, nörolojik hastalıkları (Alzheimer gibi) ve bunların riskini azalttığını göstermektedir. ${ }^{46}$

A vitamini hayvansal ve bitkisel dokularda bulunur. Retinoid ve karotenoidler halinde bulunan A vitamini, genellikle sarı, turuncu ve yeşil sebzelerde ve meyvelerde yer alır. Karetonoidler, serbest radikallere karşı koruyucu, immün sistemi güçlendirici, hücreler arası sinyal yolaklarını iyileştiricidir. AH'li hastalarda plazma düzeylerinde lutein ve zeaksantin seviyelerinin düşük olduğu görülmüştür. ${ }^{47-49}$

Yapılan bir çalışmada, lutein ve zeaksantinin antioksidan ve anti-inflamatuar özellikleriyle hücreleri dolayısı ile beyin hücrelerini korumada etkili olduğu gösterilmiştir. Diyetle alınan astaksantin de yine güçlü bir antioksidan olduğu için beyin işlevleri üzerinde olumlu etkiler göstermektedir. ${ }^{50-51}$

Antioksidan özelliği ile öne çıkan $\mathrm{E}$ vitamininin $\alpha$ tokoferol formu, biyoyararlılık açısından en faydalı formdur. Düşük plazma seviyesi, apolipoprotein e4 taşınımının artışını sağlar ve bu bilişsel bozukluğa neden olur. Dolayısı ile yüksek E vitamini seviyesinin $\mathrm{AH}$ ile ters orantılı olacağı düşünülmektedir. ${ }^{52} \mathrm{~B}$ vitaminleri nörolojik sistem üzerinde birçok fonksiyona sahiptir. B12 vitamini eksikliğinde dejenerasyon, B6 vitamini eksikliğinde pellegra, B1 vitamini eksikliğinde görülen Wernicke- Korsakoff demansı $\mathrm{B}$ vitaminine özgü hastalıklardır. ${ }^{53} \mathrm{~B}$ vitaminleri eksiklikleri bilişsel işlevlerin disfonksiyonuna neden olan faktörlerden biridir. ${ }^{54}$ Kronikleşen D vitamini eksikliği ile AH ve diğer demans hastalıkları arasında bir ilişki olduğunu gösteren çalışmalar mevcuttur. ${ }^{55-57} \mathrm{D}$ vitamini bilinen metabolizma olaylarının yanında psikolojik işleyiş ve merkezi sinir sisteminin korunmasında da rolü vardır. Genel olarak yapılan çalışmalar tarandığında yaşlılarda $\mathrm{D}$ vitamini düzeyi plazmada düşüktür ve bu bilişsel fonksiyonlarda işlev kaybına neden olmaktadır. ${ }^{58}$ Selenyum elzem bir elementtir ve vücutta selenoproteinlerin oluşumunda rol oynar. Bu proteinler antioksidan özellik gösterirler ve selenyumun plazmada düşük olmasının demans ile ilişkisi olabileceği düşünülse de daha çok çalışmaya ihtiyaç vardir. $^{59}$

\section{Omega 3 ile İlişkisi}

Doymuş ve trans yağların diyette tüketiminin artması ile AH riskinin arttığı, doymamış yağların tüketiminin ise AH riskini azalttığı bilinmektedir. Yapılan hayvan deneylerinde balık yağının amiloid beta birikimini önlediği gösterilmiştir. ${ }^{60}$ Birçok çalışma AH ile omega3 yağ asitleri tüketimi arasında zıt ilişki olduğunu göstermektedir. Haftada en az bir kez balık tüketenler ile daha az tüketenler karşılaştırıldığında tüketmeyenlerde $\% 60$ oranında $\mathrm{AH}$ riskinin arttığ1 bilinmektedir. ${ }^{61-62}$

AH'nin önerilen spesifik bir tedavi diyeti olmasa da bazı besin ögeleri koruyucu sayılmaktadır. Sağlıklı yağ asitleri, antioksidanlar, balık tüketimi, homosistein/metionin dengesi, vitaminler ve 1limlı alkol alımı bunlardan biridir. Balık yağında bulunan yağ asitlerinin $\mathrm{AH}$ üzerinde koruyuculuğu vardır. ${ }^{63}$

\section{Polifenoller ile İlişkisi}

Diyetin antioksidanları polifenollerdir. Yapıtaşlarındaki aromatik halkalar ve diğer bileşiklere göre sınıflandırılırlar ve flavonoidler polifenollerin en büyük kısmını oluşturup flavonoller, izoflavonlar, antosiyaninler, flavanoller, flavonlar, flavanonlar olarak sinıflandırılırlar. ${ }^{64}$ Son dönemlerde yapılan çalışmalar, flavonoidlerin nörolojik hastalıklar üzerindeki tedavi edici etkisi üzerine yoğunlaşmaktadır. Sonuç olarak flavonoidlerin nörodejenerasyonu engellediği veya hafiflettiği düşünülmektedir ve bu mekanizmanın inflamasyon aracılarını düzenleyerek yaptığı belirtilmektedir. ${ }^{65-70}$

Elma, portakal, limon, soğan, patates, karnabahar, çay, kahve yüksek miktarda flavonoid içerirler. ${ }^{71,72}$ Flavonoidlerin diğer antioksidanlarla beraber birçok hastalığa karşı koruyucu oldukları söylenmektedir. ${ }^{72}$ Flavonoidlerin, antiviral, antialerjenik, antikoagülan, antiinflamatuar özellikleri sayesinde tedavi edici olduğu bilinmektedir. ${ }^{73}$

\section{Mikrobiyota ile İlişkisi}

Mikrobiyota bireysel farklılıklara göre şekil almaktadır. Genetik yatkınlık, diyet, bağırsak bakterilerinin türü hastalık riskini şekillendirmektedir. Bağırsaklarda kompleks bir sinir sistemi vardır ve merkezi sinir sistemi (MSS) ile arasında bir bağlantı vardır. Mikrobiyota, hastalık yapan bakterilere karş1 koruma, gıda emilimini etkileme, sağlığı koruma gibi görevler üstlenmektedir. ${ }^{74}$ Yapılan çalışmalara göre, mikrobiyota bilişsel aktivite dahil birçok beyin işlevi üzerinde bağırsak-beyin aksı sayesinde etkisini göstermektedir. Tüketilen besinler ve besinlerin kaynakları, kullanılan ilaçlar, alınan probiyotik takviyeleri $\mathrm{AH}$ riskini artıran veya azaltan etkenlerdendir. Bağırsaktaki iyi-kötü bakteri dengesi ve bağırsak yapısı da $\mathrm{AH}$ riskinde etkilidir. Bağırsak- 
beyin aksındaki işlev kaybı nörodejenerasyon görülme sıklığını arttırmaktadır. Mikrobiyota kaynaklı sebeplerden AH'nin başlayabildiği veya bu durumun hastalık riskini artırdığı yapılan çalışmalarca gösterilmiştir. Sağlıklı bir mikrobiyota AH için terapötik olabilir. ${ }^{75-77}$

AH'nın patagonezinde, inflamasyonun varlığından bahsedilmektedir. Bifidobakteri içeren probiyotiklerin, AH'de bilişsel işlevler üzerinde olumlu etkiler göstermektedir. Bunun yanısıra diyet polifenollerinin ve bazı prebiyotik özellikleri olan bitkisel ürünlerin bozulmuş bağırsak aktivitesini iyileştirdiği, serbest radikal oluşumunu azalttığı ve $\mathrm{AH}$ başlangıcını önlemek için etkili olmaktadır. ${ }^{78} \mathrm{AH}$ ve yaşlanma ile ilgili yapılan bir çalışmada mikrobiyotanın, inflamasyon üzerindeki etkisi araştırılmıştır. İnflamasyon süresinde, sadece bir hafta kullanilan probiyotiğin, inflamasyonun bağırsakta meydana getirdiği bakteri dengesizliğini düzenlediği gösterilmiştir. ${ }^{79}$ İnflamasyonun hiperinsulinemi ve dislipidemiye neden olduğu bilinmektedir. Hiperinsulinemi ile ilişkili insülin direncinin de dolaylı olarak AH ile ilişkili olduğu düşünülmektedir. ${ }^{80}$

Bağırsakta bulunan bakterilerin türleri arasındaki dengesizlik sonucu patojen bakteri türlerinin vücutta sayısının artmaktadır. Bacteroides fragilis isimli bakterinin, insanların çoğunda AH'nin de dahil olduğu birçok hastalığın tedavisinde olumlu sonuçlar doğurduğu belirtilmiştir. ${ }^{81}$

Egzersiz ile beraber probiyotik desteğinin alınması, vücuttaki inflamasyonu, oksidatif stresi ve amiloid beta birikimini azaltabilmektedir. Egzersiz yapmak, mikrobiyotayı olumlu yönde etkilemekte ve Alzheimer oluşumunu geciktirmektedir. Sonuç olarak egzersizin mikrobiyota üzerinde olumlu etkileri olduğu ve egzersiz ile probiyotik desteğinin birlikte bilişi iyileştirebileceği görülmüştür. ${ }^{82}$

\section{Diğer Maddeler ile İlişkisi}

Metal maruziyeti amiloid beta birikimine neden olmaktadır. Hava kirliliği, kirli toprak, kirli su, tarım ürünleri, deniz ürünleri metal maruziyetini arttıranbaşlıca faktörlerdir. Alüminyum, arsenik, kalsiyum, kadminyum, kobalt, bakır, demir, cıva, kurşun, selenyum, çinko bu metallerdendir. ${ }^{83-84} \mathrm{AH}$ 'de beyinde alüminyum birikimi olduğu gözlenmiştir. Alüminyum aynı zamanda nöropati, oksidatif stres ve inflamasyon yarattığı için de AH için risk kaynağıdır. Alüminyumun amiloid beta birikiminde çapraz bağlayıcı olduğu görülmüştür fakat daha fazla çalışmaya ihtiyaç vardır. Yiyecek veya su ile alınan alüminyumun akut dönemde herhangi bir toksisite yarattığ 1 vaka bilinmemektedir ancak uzun süreli maruziyette zararlı etkileri olmaktadır. Yapılan hayvan çalışmasında içme suyu ile alüminyuma maruz kalındığında $\mathrm{AH}$ ile ilişki olabileceği düşünülmüştür.
İçme suyunda alüminyum yoğunluğu $\geq 100 \mathrm{mg} / \mathrm{l}$ olduğunda $\mathrm{AH}$ gelişme riski başlamaktadir. ${ }^{85} \mathrm{AH}$ 'den etkilenen beyin bölgelerinde süperoksit dismutaz, sitokrom C oksdiaz gibi yapısında bakır bulunan enzimlerin aktivitesi azalmaktadır ve bu nedenle $\mathrm{AH}$ ile ilişkili olabilmektedir. Diyetle yüksek bakır alımı, amiloid beta benzeri yapılar ile öğrenme eksikliklerini ortaya çıkarmaktadır. ${ }^{86-87}$

Kurşun maruziyeti, fizyolojik gelişimi etkilemesi sebebiyle nörodejenerasyonu ve AH'ye yatkınlığ 1 artırabilmektedir. ${ }^{88}$ Kobalt birikiminin ise nörolojik durum üzerinde ve sinirsel iletide olumsuz etkileri olduğu bildirilmiştir. ${ }^{89,90}$ Civanın sinirlerde biriktiği bilinmektedir. Yapılan çalışmalar cıvanın Tau proteinini, amiloid beta birikimini etkilediğini göstermektedir. AH'da kanda cıva düzeyi yüksek olarak belirtilmiştir. ${ }^{91,92}$ Arsenik miktarının çok az olması bile nörolojik ve psikolojik bozukluklarla ilişkili olduğunu araştırmalar göstermektedir. ${ }^{93}$ Kalsiyum konsantrasyonu fizyolojik durumlara bağlı olarak vücut tarafindan sıkı bir şekilde denetlenerek düzenlenir. Yüksek serum kalsiyum düzeyinin apolipoprotein e4 ekspresyonunu etkilediği ve amiloid beta birikimini indüklediği Tau proteininin fosforilasyonunu artırdığı ve bunlarla AH'nin patofizyolojine etki ettiği bilinmektedir. Kalsiyum salınımın azalması nöroprotektif bir etki gösterir. ${ }^{94}$

\section{SONUÇ}

Sonuç olarak Alzheimer Hastalığı geri dönüşü olmayan ve beslenme ile tedavi edilemeyen nörolojik bir hastalıktır. Beslenme, kişiye özgü ve Alzheimerlı bireyin ihtiyaçlarına yönelik planlandığında kişi için hastalığın seyri sırasında hayat kalitesini artırıcı ve semptomları yavaşlatıcı olabilir. Alzheimer hastalarında beslenme problemlerinin hastalığın ilerlemesi ile görüleceği unutulmamalı ve takip edilen diyet planının buna göre şekillenmesi gerekmektedir. Günümüzde kabul gören Akdeniz Diyeti bireyler için uygun olup; antioksidan kapasitesi yüksek, amiloid beta birikimine sebep olan maruziyetlerden uzak, inflamasyonu azaltan diyet programlarını önermek, AH geni taşıyan bireylerde koruyucu olabilmektedir. Gün geçtikçe yapılan araştırma sayısı artmaktadır ve henüz tam olarak anlaşılmamış olan $\mathrm{AH}$ için daha fazla araştırmaya gerek vardır.

\section{KAYNAKLAR}

1. Gürvit İH. Demans sendromu, alzheimer hastalığı ve alzheimer dışı demanslar. In: Öge AE. Nöroloji. İstanbul: Nobel Tıp Kitabevleri; 2004:367- 415.

2. Vilatela MEA, López-López M, Yescas-Gómez P. Genetics of Alzheimer's disease. Arch Med Res. 2012; 43(8):622-631.

3. Goedert M, Spillantini MG. A century of Alzheimer's disease. Science. 2006; 314(5800): 777-781.

4. Cankurtaran M, Yavuz BB, Halil M, Dagli N, Cankurtaran ES, Ariogul S. Are serum lipid and 
lipoprotein levels related to dementia? Arch Gerontol Geriatr. 2005;41(1):31-39.

5. Mucke L. Alzheimer's disease. Nature. 2009; 461(7266):895-897

6. Jiang C, Li G, Huang P, Liu Z, Zhao B. The gut microbiota and Alzheimer's disease. J Alzheimers Dis. 2017;58(1):1-15.

7. Knopman DS. Preclinical Alzheimer disease- the new frontier. Nat Rev Neurol. 2016;12(11):620-621.

8. McKhann GM, Knopman DS, Chertkow H, Hyman BT, Jack Jr CR, Kawas CH, et al. The diagnosis of dementia due to Alzheimer's disease: Recommendations from the National Institute on Aging-Alzheimer's Association Workgroups on diagnostic guidelines for Alzheimer's disease. Alzheimers Dement. 2011:7(3):263-269.

9. World Health Organization (WHO). Towards a dementia plan: A WHO guide. https://www.who.int/mental health/neurology/dementi a/policy guidance/en/ Accessed September 24, 2020.

10. Castro DM, Dillon C, Machnicki G. Allegri RF. The economic cost of Alzheimer's Disease: Family or public-health burden? Dementia and Neuropsychologia. 2010:4(4):262-267.

11. World Alzheimer Report. World Alzheimer Report 2015: The global impact of dementia. https://www.alz.co.uk/research/world-report-2015 Accessed September 24, 2020.

12. Bekris LM, Yu CE, Bird TD, Tsuang DW. Genetics of Alzheimer disease. J Geriatr Psychiatry Neurol. 2010; 23(4):213-227.

13. Öge AE, Baykan B. Nöroloji. 2. Bask1. İstanbul: Nobel Tip Kitabevleri; 2005;730.

14. Jack CR Jr, Knopman DS, Jagust WJ, et al. Hypothetical model of dynamic biomarkers of the Alzheimer's pathological cascade. Lancet Neurol. 2010;9(1):119128.

15. Selekler K. Alois Alzheimer ve Alzheimer Hastalığı. Turkish Journal of Geriatrics. 2010;13(3):9-14.

16. Qui C, Kivipelto M, von Strauss E, Epidemiology of Alzheimer's disease: occurence, determinants, and strategies toward intervention. Dialogues Clin Neurosci. 2009;11(2):111-128.

17. Gürvit H, Emre M, Tinaz Ş, et al. The prevalance of dementia in an urban Turkish population. Am J Alzheimers Dis Other Dement. 2008;23(1):67-76. doi: $10.1177 / 1533317507310570$.

18. Özpak L, Pazarbaşı A, Keser N. Alzheimer hastlalığının genetiği ve epigenetiği. Arşiv Kaynak Tarama Dergisi. 2017;26(1):34-49

19. Markesbery WR, Ehmann WD (Çev. B Bilgiç). Alzheimer Hastalığında oksidatif gerilim. In Alzheimer Hastalığ (Eds RD Terry, R Katzman, KL Bick, SS Sisodia (Çev. Ed. H Gürvit). İstanbul:Yelkovan Yayınclik;2001:401-414.

20. Smith MA, Nunomura A, Lee HG, et al. Chronological primacy of oxidative stress in Alzheimer disease. Neurobiology Aging. 2005;26:579-80. doi:10.1016/j.neurobiolaging.2004.09.021.

21. Viola KL, Klein WL, Amyloid $\beta$ oligomers in Alzheimer's disease pathogenesis, treatment, and diagnosis. Acta Neuropathol. 2015;129(2):183-206. doi:10.1007/s00401-015-1386-3.

22. Grammas P. Neurovascular dysfunction, inflammation and endothelial activation: Implications for the pathogenesis of Alzheimer's disease. $J$ Neuroinflammation. 2011;8:26. doi:10.1186/17422094-8-26.
23. Craft S, Cholerton B, Baker LD. Insulin and Alzheimer's disease: untangling the web. $J$ Alzheimers Dis. 2013;33:263-275. doi: 10.3233/JAD-2012-129042.

24. Ridge PG, Ebbert MT, Kauwe JS, Genetics of Alzheimer's disease. Biomed Res Int. 2014;2014:254954. doi: 10.1155/2013/254954.

25. Apostolova LG. Alzheimer's disease. Continuиm (Minneap Minn). 2016;22(2):419-434. doi: 10.1212/CON.0000000000000307.

26. Yegambaram M, Manivannan B, Beach TG, Halden RU. Role of environmental contaminants in the etiology of Alzheimer's disease: a review. Curr Alzheimer Res. 2015;12(2):116-146.

27. Vermeer SE, den Heijer T, Koudstaal PJ, Oudkerk M, Hofman A, Breteler MM. Incidence and risk factors of silent brain infarcts in the population based Rotterdam Scan Study. Stroke. 2003;34:392-396. doi:10.1161/01.STR.0000052631.98405.15.

28. Rivera EJ, Goldin A, Fulmer N, Tavares R, Wands JR, de la Monte SM. Insulin and insulin-like growth factor expression and function deteriorate with progression of Alzheimer's disease: link to brain reductions in acetylcholine. J Alzheimers Dis. 2005;8(3):247-268.

29. Yeşilkaya B, Tüfekçi Alphan ME. Tip 2 diyabetlilerde yaşam kalitesinin değerlendirilmesi. International Peer-reviewed Journal of Nutrition Research. 2018;13:1-16.

30. Reed B, Villeneuve S, Mack W, Decarli C, Chui HC, Jagust W. Associations between serum cholesterol levels and cerebral amyloidosis. JAMA Neurol. 2014;71(2):195-200.

31. Presecki P, Seler D, Mimica N, et al. Serum lipid levels in patients with Alzheimer's disease. Collegium Antropologicum. 2011;35(1):115-120.

32. Wang J, Gu BJ, Masters CL, Wang YJ. A systemic view of Alzheimer disease-insights from amyloid- $\beta$ metabolism beyond the brain. Nat Rev Neurol. 2017;13(10):612-623.

33. Soner $S$, Aykut $S$. Alzheimer hastalığı sürecinde bakım veren aile üyelerinin yaşadıkları güçlükler ve sosyal hizmet. AEÜSBED. 2017;2(3):375-387.

34. Salmon DP. Neuropsychological features of mild cognitive impairment and preclinical Alzheimer's disease. Curr Top Behav Neurosci. 2012;10:187-212.

35. Kutluay Merdol T. Sağlıklı yaşamak için doğru diyet planı uygulamak bir gerekliliktir. Bes Diy Derg. 2017;45(1):1-2.

36. Canbolat E, Yardımc $H$. Alzheimer hastalığı ve koruyucu besin ögeleri. DÜ Sağllk Bil Enst Derg. 2016;6(2):139-145.

37. Sofi F, Cesari F, Abbate R, Gensini GF, Casini A, Adherence to Mediterranean diet and health status: meta-analysis. BMJ. 2008;337. doi: 10.1136/bmj.a1344.

38. Swaminathan A, Jicha GA. Nutrition and prevention of Alzheimer's dementia. Front Aging Neurosci. 2014;6:282.

39. Davis C, Bryan J, Hodgson J, Murphy K. Definition of the mediterranean diet: a literature review. Nutrients. 2015;7(11):9139-53. doi:10.3390/nu7115459.

40. Bach-Faig A, Berry EM, Lairon D, et al. Mediterranean diet pyramid today: science and cultural updates. Public Health Nutr. 2011;14(12A):2274-84.

41. Akgüllü Ç, Sırıken F, Eryılmaz U, et al. The relation between compliance to the Mediterranean diet and the extensiveness of coronary artery disease. Turk Kardiyol Dern Ars. 2015;43(4):340- 9. 
42. Gönder M, Akbulut G. Güncel Akdeniz diyeti ve potansiyel sağllk etkileri. Türkiye Klinikleri $J$ Health Sci. 2017;2(2):110-20.

43. Gu Y, Luchsinger JA, Stern Y, Scarmeas Y. Mediterranean diet, inflammatory and metabolic biomarkers, and risk of Alzheimer's disease. J Alzheimers Dis. 2010;22(2):483-92. doi:10.3233/JAD2010-100897.

44. Dai J, Jones DP, Goldberg J, et al. Association between adherence to the mediterranean diet and oxidative stress. Am J Clin Nutr. 2008;88(5):1364-1370.

45. Frisardi V, Panza F, Seripa D, et al. Nutraceutical properties of Mediterranean diet and cognitive decline: possible underlying mechanisms. J Alzheimers Dis. 2010;22(3):715-740.

46. Szajdek A, Borowska EJ. Bioactive compounds and health-promoting properties of berry fruits: a review. Plant Foods Hum Nutr. 2008;63(4):147-156.

47. Baysal A. Beslenme. 12. Baskı. Ankara, Hatipoğlu Yayınlar1; 2009.

48. Yeum KJ, Russell RM. Carotenoid bioavailability and bioconversion. Annu Rev Nutr. 2002;22:483-504. doi: 10.1146/annurev.nutr.22.010402.102834

49. Nolan JM, Loskutova E, Howard A, et al. The impact of supplemental macular carotenoids in Alzheimer's disease: a randomized clinical trial. J Alzheimers Dis. 2015;44(4):1157-1169.

50. Renzi LM, Bovier ER, Hammond BR. A role for the macular carotenoids in visual motor response. Nutr Neurosci. 2013;16(6):262-268.

51. Manabe Y, Komatsu T, Seki S, Sugawara T. Dietary astaxanthin can accumulate in the brain of rats. Biosci Biotechnol Biochem. 2018;82(8):1433-1436.

52. Fata GL, Weber P, Mohajeri MH. Effects of vitamin E on cognitive performance during ageing and in Alzheimer's disease. Nutrients. 2014;6(12):5453-5472. doi: $10.3390 /$ nu6125453.

53. Swaminath A, Jicha GA. Nutrition and prevention of alzheimer's dementia. Front Aging Neuroscience. 2014;6:1-13. doi:10.3389/fnagi.2014.00282.

54. Douaud G, Refsum H, de Jager CA, et al. Preventing alzheimer's disease- related gray matter atrophy by $\mathrm{B}$ vitamin treatment. PNAS. 2013;110(23):9523-9528. doi:10.1073/pnas.1301816110.

55. Llewellyn DJ, Langa KM, Lang IA. Serum 25hydroxyvitamin D concentration and cognitive impairment. J Geriatr Psychiatry Neurol. 2009;(3):188195. doi: $10.1177 / 0891988708327888$.

56. Gezen Ak D, Y1lmazer S, Dursun E, Why vitamin D in Alzheimer's disease. The hypothesis. J Alzheimers Dis. 2014;40(2):257-269. doi:10.3233/JAD-131970.

57. Banerjee A, Khemka VK, Ganguly A, Roy D, Ganguly U, Chakrabarti S. Vitamin D and Alzheimer's disease: neurocognition to therapeutics. Int $J$ Alzheimers Dis. 2015;192747. doi:10.1155/2015/192747.

58. Annweiler C, Beauchet O. Vitamin D-mentia: randomized clinical trials should be the next step. Neuroepidemiology. 2011;37(3-4):249-258.

59. Cardoso B, Cominetti C, Cozzolino S. Importance and management of micronutrient deficiencies in patients with Alzheimer's disease. Clin Interv Aging. 2013;8: 531-542. doi: 10.2147/CIA.S27983.

60. Friedland RP. Fish consumption and the risk of alzheimer disease. Arch Neurol. 2003;60(7):923-924.

61. Yiğit Y, Ay E. Fonksiyonel gida özelliğiyle ceviz ve Kaman cevizi, 2006;1(2):143-153.
62. Canbulat Z, Özcan T. Süt ürünlerinin EPA ve DHA ile zenginleştirilmesi. Türkiye 10. Glda Kongresi, 21-23 May1s, 2008:713-716.

63. Petot GJ, Friedland RP. Lipids, diet and Alzheimer disease: an extended summary. J Neurol Sci. 2004; 226:31-33. doi:10.1016/j.jns.2004.09.007.

64. Beecher Gr. Overview of dietary flavonoids: nomenclature, occurrence and intake. $J$ Nutr. 2003;133(10):3248-3254.

65. Choi SM, Kim BC, Cho YH, et al. Effects of flavonoid compounds on $\beta$-amyloid-peptide-induced neuronal death in cultured mouse cortical neurons. Chonnam Med J. 2015;50(2):45-51.

66. Cui QJ, Wang LY, Wei ZX, Qu WS. Continual naringin treatment benefits the recovery of traumatic brain injury in rats through reducing oxidative and inflammatory alterations. Neurochem Res. 2014;39(7):1254-1262.

67. Jung UJ, Jeon MT, Choi MS, Kim SR. Silibinin attenuates MPP+-induced neurotoxicity in the substantia nigra in vivo. J Med Food. 2014;17(5)599605.

68. Lee E, Park HR, Ji ST, Lee Y, Lee J. Baicalein attenuates astroglial activation in the 1-methyl-4phenyl-1,2,3,4-tetrahydropyridine-induced Parkinson's disease model by downregulating the activations of nuclear factor- $\mathrm{\kappa B}$, ERK, and JNK. J Neurosci Res. 2014;92(1):130-139. doi:10.1902/jnr.23307.

69. Vafeiadou K, Vauzour D, Lee HY, Rodriguez-Mateos A, Williams RJ, Spencer JP. The citrus flavanone naringenin inhibits inflammatory signalling in glial cells and protects against neuroinflammatory injury. Arch Biochem Biophys. 2009;484(1):100-109. doi: 10.1016/j.abb.2009.10.016.

70. Vauzour D, Vafeiadou K, Rodriguez-Mateos A, Rendeiro C, Spencer JP. The neuroprotective potential of flavonoids: a multiplicity of effects. Genes Nutr. 2008;3(3- 4):115-126.

71. Manach C, Scalbert A, Morand C, Rémésy C, Jiménez L. Polyphenols: food sources and bioavailability. Am J Clin Nutr. 2004;79:727-747.

72. Rodrigo R, Libuy M, Feliu F, Hasson D. Polyphenols in disease: from diet to supplements. Curr Pharm Biotechnol. 2014;15(4):304-317.

73. Wang HK, The therapeutic potential of flavonoids. Expert Opin Investig Drugs. 2000;9(9)2103-2109. doi: 10.1517/13543784.9.9.2103.

74. Hu X, Wang T, Jin F, Alzheimer's disease and gut microbiota. Sclence China Life Sci. 2016;59(10):10061023. doi: 10.1007/s11427-016-5083-9.

75. Hooper LV, Gordon JI. Commensal host-bacterial relationships in the gut. Science. 2001;292(5519): 11151118. doi:10.1126/science.1058709.

76. Ley RE, Turnbaugh PJ, Klein S, Gordon JI. Microbial ecology: human gut microbes associated with obesity. Nature. 2006;444(7122):1022-1023.

77. Arumugam M, Raes J, Pelletier E, et al. Enterotypes of the human gut microbiome. Nature. 2011;473(7346):174-180.

78. Mancuso C, Santangelo R. Alzheimer's disease and gut microbiota modifications: the long way between preclinical studies and clinical evidence. Pharmacological Res. 2017;129:329-336. doi:10.1016/j.phrs.2017.12.009.

79. Gareau MG, Wine E, Rodrigues DM, et al. Bacterial infection causes stress-induced memory dysfunction in mice. Gut Microbiota. 2011;60:307-317. 
80. Kouchaki E, Tamtaji OR, Salami M, et al. Clinical and metabolic response to probiotic supplementation in patients with multiple sclerosis: a randomized, doubleblind, placebo-controlled trial. Clin Nutr. 2017;36(5):1245-1249.

81. Fung TC, Olson CA, Hsiao EY. Interactions between the microbiota, immuneand nervous system in health and disease. Nat Neurosci. 2017;20:145-155.

82. Abraham D, Felszeghy K, Feher J, Radak Z. Interval training and probiotic supplementation a new prospect in the prevention of Alzheimers disease. Free Radical Biology and Medicine. 2016;96:17-18.

83. Tchounwou P, Yedjou C, Patlolla A, Sutton D. Heavy metal toxicity and the environment. 2012;(101)133-164. doi:10.1007/978-3-7643-8340-4_6.

84. Kawahara M, Kato-Negishi M. Link between aluminum and the pathogenesis of Alzheimer's disease: the integration of the aluminum and amyloid cascade hypotheses. Int $J$ Alzheimers Dis. 2011;276393. doi:10.4061/2011/276393.

85. Campbell A, The potential role of aluminium in Alzheimer's disease. Nephrol Dial Transplant. 2002;17 (2):17-20. doi:10.1093/ndt/17.suppl_2.17.

86. Singh I, Sagare AP, Coma M, et al. Low levels of copper disrupt brain amyloid- $\beta$ homeostasis by alter- ing its production and clearance. Proc Natl Acad Sci U S A. 2013;110(36):14771-14776.

87. Squitti R, Polimanti R. Copper phenotype in Alzheimer's disease: dissecting the pathway. Am J Neurodegener Dis. 2013;2(2):46-56.

88. Basha MR, Wei W, Bakheet SA, et al. The fetal basis of amyloidogenesis: exposure to lead and latent overexpression of amyloid precursor protein and ßamyloid in the aging brain. $J$ Neurosci. 2005;25(4):823-829.
89. Kim JH, Gibb HJ, Howe PD. WHO Concise Inernational Chemical Assessment Document; 69. Cobalt and inorganic cobalt compounds; 2006. https://apps.who.int/iris/handle/10665/43426

90. Matés JM, Segura JA, Alonso FJ, Márquez J. Roles of dioxins and heavy metals in cancer and neurological diseases using ROS mediated mechanisms. Free Radical Biol Med. 2010;49(9):1328-1341.

91. Pigatto PD, Costa A, Guzzi G. Are mercury and Alzheimer's disease linked? Science of the Total Enviroment. 2018;613-614:1579-1580.

92. Mutter J, Curth A, Naumann J, Deth R, Walach H. Does inorganic mercuy play a role in Alzheimer's disease. A systematic review and an integrated molecular mechanism. J Alzheimers Dis. 2010;22(2):357-374.

93. O'Bryant SE, Edwards M, Menon CV, Gong G, Barber R. Long-term 1 -level arsenic exposure is associated with poorer neuropsychological functioning: a project frontier study. Int $J$ Environ Res Public Health. 2011;8(3):861-874. doi:10.3390/ijerph8030861.

94. Wang P, Wang ZY. Metal ions influx is a double edged sword for the athogenesis of Alzheimer's disease Ageing Res Rev. 2017;35:265-290. doi:10.1016/j.arr.2016.10.003. 